\title{
The Use of Karelia's High-Mg Rocks for the Production of Building Materials, Ceramics and Other Materials with Improved Properties
}

\author{
V. Ilyina ${ }^{(\bowtie)}$ \\ Institute of Geology KarRC RAS, Petrozavodsk, Russia \\ Ilyina@igkrc.ru
}

\begin{abstract}
The possible use of high-Mg host rocks, such as serpentinite and pyroxenite, from the Aganozero chromium ore deposit and serpentinite from the Ozerki soapstone deposit, Republic of Karelia, for the production of heatinsulating building materials, ceramic pigments and filters for purification of technogenous solutions is assessed. The results of analysis of the mineralogical compositions of serpentinites and pyroxenite, as well as the physico-mechanical properties (strength, heat conductivity, shrinkage upon roasting, moisture resistance, etc.) and structural characteristics of the ceramic and heat-insulating materials produced on their basis are reported.
\end{abstract}

Keywords: Serpentinite $\cdot$ Pyroxenite $\cdot$ Ceramics $\cdot$ Heat conductivity $\cdot$ Mechanical strength $\cdot$ Facing material

\section{Introduction}

Non-conventional high-Mg rocks can be used for the production of ceramic, building and other materials because they are widespread but mainly because of the chemical, mineral and structural characteristics of their mineral constituents: periclase, forsterite, diopside, augite, enstatite and serpentine. The main high-Mg mineral constituents of ceramics suffer phase transformations upon heating, as a result of the disintegration and recrystallization of their lattice (Deere et al. 1965), forming crystalline phases that improve the physic-mechanical properties of ceramics. As forsteritic ceramics suffers no polymorphic transformations, it does not age and is mechanically strong. It is used for the production of dielectrics, heat-insulating materials, facing ceramics and filters for water purification. The aim of the present project is to study serpentinites, kemistites (rocks of hydrotalcite-serpentine composition) and pyroxenites that host chromium ores at the Aganozero deposit and serpentinites at the Ozerki soapstone deposit and to use them for the production of ceramics with a dominant forsteritic crystalline phase, filters for purification of technogenic solutions and ceramic pigments. 


\section{Methods and Approaches}

The mineral composition of the analyzed samples was studied in the IG KarRC RAS by optical microscopy methods, X-ray phase analysis (XPA) and thermal analysis (TA). Rock-forming minerals were studied by Vega II LSH scanning electron microscope with INCA Energy 350 energy dispersion analyzer. X-ray phase analysis was performed by ARL X'TRA diffractometer with $\mathrm{CuKl}$ radiation. The physico-mechanical properties of the materials and ceramics were assessed in accordance with State AllRussia standards.

\section{Results and Discussion}

Differences in the mineral composition of serpentinites affect their chemical composition. Aganozero kemistites and serpentinites are the richest in magnesium (36-38\%) and contain minor quantities of impurities $\left(0.1-0.5 \% \mathrm{Al}_{2} \mathrm{O}_{3}\right.$ and $\left.0.24-0.5 \% \mathrm{CaO}\right)$ and elevated quantities of crystallization water (loss on ignition is 15-18.5\%). Ozerki serpentinite is rich in $\mathrm{MgO}(36.92 \%)$ and contains $\mathrm{Al}_{2} \mathrm{O}_{3}(2.2)$ and $\mathrm{CaO}(0.22 \%)$ as impurities. All the samples are iron-rich (3.46-10.02\% $\left.\mathrm{Fe}_{2} \mathrm{O}_{3}, 1.72-3.9 \% \mathrm{FeO}\right)$. The mineralogo-analytical study (RPA, TA) of serpentinites showed that Ozerki serpentinites consisted of $89.1 \%$ fine-grained lamellar antigorite aggregate and that Aganozero serpentinites contained $78 \%$ lizardite. Ore minerals are represented by magnetite and ilmenite. The main minerals of natural pyroxenite $(w t \%)$ are augite $(67,2)$, forsterite $(4,3)$, enstatite $(23,7)$ and serpentine $(4,8)$. Kemistite-based porous heatinsulating ceramics was developed and its properties were studied (Patent no. 2497774, 2013). Electron microscopy study has shown that forsterite, produced by serpentine recrystallization, is the main crystal-line phase of heat-insulating ceramics. The properties of heat-insulating ceramics are shown in Fig. 1.

Pyroxenite (20-70\%) and hydromica-based facing ceramics (Il'ina et al. 2017) displays water absorption of $13-15.8 \%$ at a roasting temperature of $900-1100{ }^{\circ} \mathrm{C}$, which is consistent with the current standards. At $1200{ }^{\circ} \mathrm{C}$, the water absorption of all the masses decreases rapidly from 0 to $1.2 \%$. Their bending strength is 9-10 MPa.

Pyroxenite-based ceramic pigment has been developed. Unlike the well-known pigment, it can be used to obtain a stable color after roasting over a wide temperature of $750-1250{ }^{\circ} \mathrm{C}$.

The results obtained (Ilyina et al. 2018) show that Ozerki serpentinite can be used for the production of an Mg-silicate reagent for the removal of heavy metals from solutions, e.g. the removal of heavy metal compounds from highly polluted technogenous solutions by filtration through loading from a granulated reagent. 


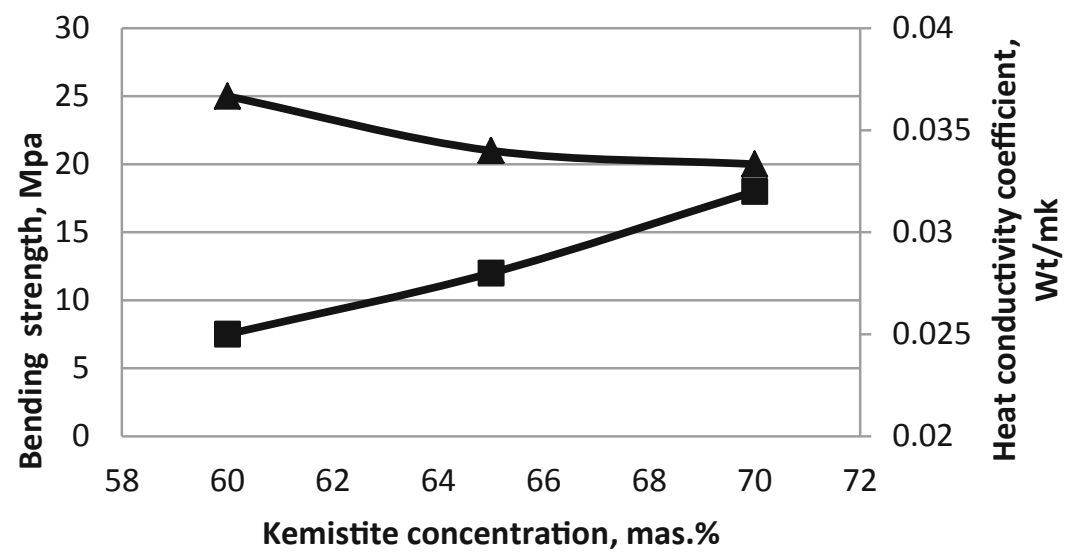

$\longrightarrow$ Strength $\rightarrow$ Heat conductivity coefficient

Fig. 1. Dependence of variations in the properties of ceramics on kemistite concentration

\section{Conclusions}

The materials developed display a porous structure and, consequently, low density, low heat conductivity and high strength. Hence, they can be widely used in industrial and civil engineering for the insulation of buildings, for the heat insulation of the hot surfaces of equipment (furnaces and pipelines), for intensifying high temperature processes and for fuel saving.

\section{References}

Deere WA, Haui RA, Zoosman J (1965) Rock-forming minerals. Chain silicated. vol 2, p 405 Il'ina VP, Inina IS, Frolov PV (2017) Ceramic mix based on pyroxenite and low-melting clay. Glass and Ceramics pp 1-4

Ilyina VP, Kremenetskaya IP, Gurevich BI, Klimovskaya EE, Ivashevskaya SN (2018) The study of serpentinized ultramafics from the Kareli-an-Kola Region and the production of a Mg-richsilicate reagent on their basis for the removal of heavy metals from solutions. In: 18th International Multidisciplinary Scientific GeoConference SGEM2018: Conference proceedings. STEF 92 Technology Ltd., 51 "Alexander Malinov" Blvd., 1712 Sofia, Bulgaria, Energy and Clean Technologies Issue: 4, 2. 2 July - 8 July 2018. Albena, Bulgaria, vol 18 (13), pp 207-213

Ilyina VP, Shchiptsov VV, Frolov PV (2013) Raw mixture for the pro-duction of a porous heatinsulating material, Bull no 31 Patent no 2497774 RF, MPC SO4B 33/132 
Open Access This chapter is licensed under the terms of the Creative Commons Attribution 4.0 International License (http://creativecommons.org/licenses/by/4.0/), which permits use, sharing, adaptation, distribution and reproduction in any medium or format, as long as you give appropriate credit to the original author(s) and the source, provide a link to the Creative Commons license and indicate if changes were made.

The images or other third party material in this chapter are included in the chapter's Creative Commons license, unless indicated otherwise in a credit line to the material. If material is not included in the chapter's Creative Commons license and your intended use is not permitted by statutory regulation or exceeds the permitted use, you will need to obtain permission directly from the copyright holder.

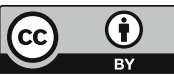

